\title{
Cryogenic Deflashing for Rubber Products
}

\author{
Abhilash M. ${ }^{1}$, G. V. Naveen Prakash ${ }^{2 *}$ and S. Kasthurirengan ${ }^{3}$ \\ ${ }^{1}$ Dept. of Mech. Engg., Maharaja Institute of Technology, Mysore, Karnataka, India \\ ${ }^{2}$ Dept. of Mech. Engg., Vidyavardhaka College of Engineering, Mysuru, Karnataka, India \\ ${ }^{3} C C T$, Indian Institute of Science, Bengaluru, Karnataka, India
}

\begin{abstract}
Deflashing is the process of removal of excess flashes from the rubber products. Initially deflashing was a manual operation where dozen of workers, seated at small work stations would take each part and trim the excess rubber off with scissors, knives or by grinding. Still the same method is employed in most of the rubber industry. The drawbacks of this method are demand inconsistent and repeatable quality. Work done by hand is often inconsistent. There are commercially available cryogenic deflashing machine but they are too expensive hence cost effectiveness is also a prime factor. The objective of this paper is to develop a technique, to identify the media through which the flashes can be removed easily and effectively. Based on the test results obtained from testing of five different types of media, ABCUT Steel media gave best results. The testing of the ABCUT Steel media on rubber samples like O-rings, grommet tail door, bottom bush etc. shows good results.
\end{abstract}

Keywords: Cryogenic deflashing, media, rubber products

\section{Introduction}

"FLASH" is a surplus rubber that oozes out between the two halves of mold during the moulding of rubber parts. In whatever technique employed to manufacture rubber products flashes cannot be avoided. The flashes can also be caused from worn mold cavities which cannot be fit together. The other reason may be due to the type of the material being molded, and its attendant viscosity in the liquid form which leads to the formation of unwanted mold flash. The one area where all the manufacturers constantly trying to improvise there gain in productivity is the region of deflashing. Earlier to the final inspection and packing, the vast majority of molded rubber parts must undergo a finishing process to remove excess flashes and this process is termed as Deflashing. [1] There have been a number of ways employed in order to remove this excess rubber flash, all of which mainly revolves around mechanical methods.

\footnotetext{
Corresponding author: gvnp@,vvce.ac.in
} 
A. Manual Deflashing: Initially deflashing was a manual operation (still many manufacturers in India employ the same). Many workers seated at small work stations would take each part and trim the excess rubber off with scissors, knives, grinders, buffing or Machine stamping. The hand deflashing has several disadvantages. The quality of work done by hand is inconsistent, generally slow and expensive due to high labour costs and also often given a poor quality finish leading to high rejection rates.

B. Vibrators and Tumbling: Vibration is the most delicate way of removing flash. This process is used where the cross sections of moulding is very thin. Tumbling of rubber components in their embrittled state is the major technique employed over the last 20 years. These are effective on a broad range of parts. They are limited, due to the reason that they are less effective on inner dimensional (ID) and on the parts which has complex configuration [7].

C. Cryogenic Shot Blast Deflashing: In this process, the parts to be deflashed slowly tumbles in a barrel (or) basket and are simultaneously blasted with media propelled by a throwing wheel. Despite its productivity the machine had relatively high cost (US $\$ 75,000$ to US $\$ 1,70,000$ ) and large space requirement put it out of reach for many molders.

Hanson Li, et al. [5] in their work compares the different deflashing methods. It gives knowledge about the advantages and disadvantages of the different deflashing methods. Maxi-Blast [6] made a review which includes an overall review on the cryogenic deflashing. It covers the growth of cryogenic deflashing starting from manual deflashing to cryogenic deflashing (the second generation). It also gave knowledge about the operational parameters which are included in the deflashing equipment such as the cycle time, wheel speed, media and the temperature.

From the literature survey found that much of the work is not carried out in the area of cryogenic deflashing in India and the commercially available cryogenic deflashing machine is too expensive. The process involved in its construction is a complex one. Hence an attempt is made to develop a cryogenic deflashing system using a simple technique and to reduce the overall cost of the system.

\section{Methodology}

Fig. 1 shows the schematic diagram of the cryogenic deflashing system. It consists of a bowl, rubber gasket, top enclosure, and a shaft carrying two cantilever beams which are placed at certain angle with respect to each other, which is connected to a motor with the help of a pulley. Fig. 2 shows the complete set up of cryogenic deflashing machine, which includes the top enclosure which has been clamped perfectly and the liquid nitrogen supply tank. 


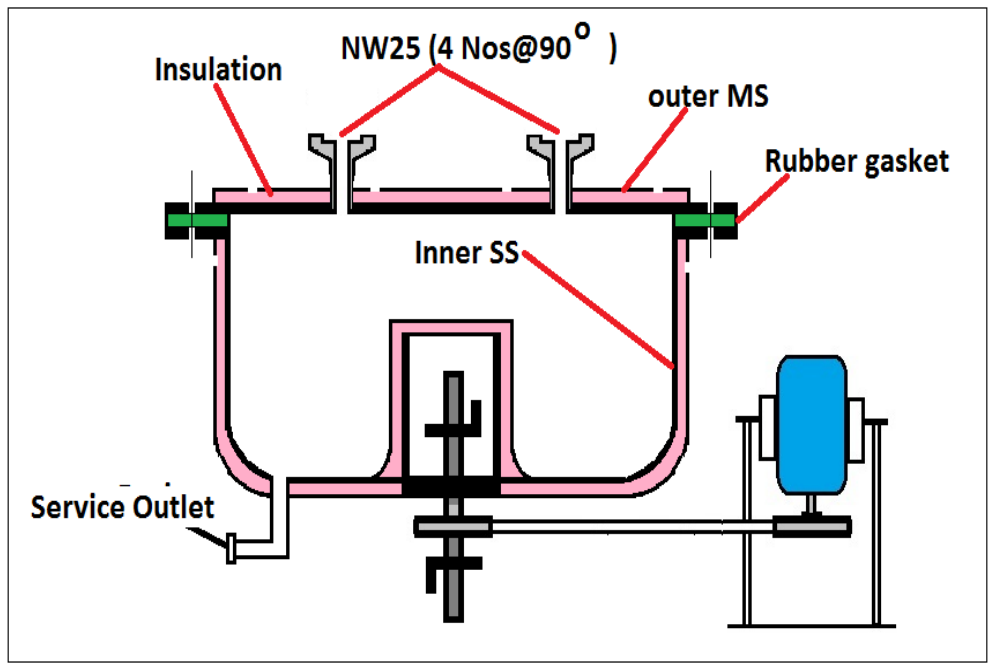

Fig. 1. Diagram of cryogenic deflashing machine

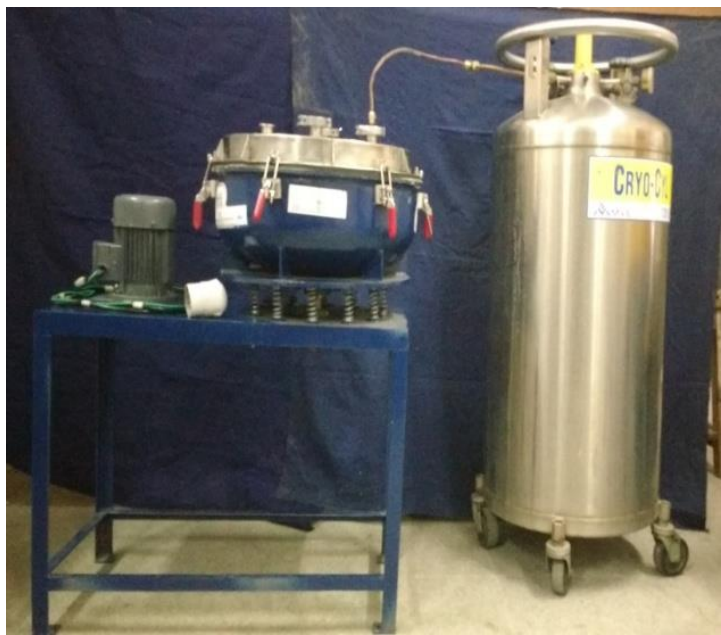

Fig. 2. Cryogenic deflashing machine

Theoretical calculation is made in order to know how much amount of liquid nitrogen is required approximately for the system in order to make a trial run.

$$
\text { Amount of heat transfer }(Q)=m \times C_{P} \times \Delta T
$$

Assumption: Material used is Stainless steel

where, $\mathrm{m}=$ mass $(\mathrm{kg})=1 \mathrm{~kg}$

$\mathrm{C}_{\mathrm{p}}($ steel $)=$ specific heat $(\mathrm{kJ} / \mathrm{kg} \cdot \mathrm{K})=530 \mathrm{~kJ} / \mathrm{kg} \cdot \mathrm{K}$

$\Delta \mathrm{T}=$ temperature difference $(\mathrm{K})$

$$
\mathrm{Q}=1 \times 530 \times(300-77)
$$




$$
\mathrm{Q}=118.19 \times 10^{3} \mathrm{~J}
$$

Latent heat of liquid nitrogen $\left(\mathrm{h}_{\mathrm{fg}}\right)=200 \mathrm{~kJ} / \mathrm{kg}$.

$$
\begin{gathered}
Q=m \times h_{f g} \\
m=\frac{Q}{\mathrm{hfg}}=\frac{118.19 \times 10^{3}}{200 \times 10^{3}} \\
\mathrm{~m}=0.59095 \mathrm{~kg}
\end{gathered}
$$

Density of liquid nitrogen $=0.807 \mathrm{~g} / \mathrm{ml}=807 \mathrm{~kg} / \mathrm{m}^{3}$

Specific volume $=\frac{1}{\text { Density }}=\frac{1}{807}=1.23911 \times 10^{-3} \mathrm{~m}^{3} / \mathrm{kg}$

Volume $=\mathrm{m} \times$ specific volume $=0.59095 \times 1.23911 \times 10^{-3}$

The amount (volume) of liquid nitrogen required per $\mathrm{kg}$ of steel $=7.3218 \times 10^{-4} \mathrm{~m}^{3}$.

$$
\text { Volume }(\text { per } \mathrm{kg})=0.732 \text { liters. }
$$

Media place a crucial role in the deflashing process. During the time of embrittlement of the rubber, impact from the media will cause the excess rubber to deflash. There are wide ranges of media available. Selection of the particular one is a tedious task. Several tests are carried out for identifying the media to be used in the system.

\section{Results \& Discussions}

Fig. 3 shows the different types of media which are available and tests were carried out on each of the media.Table1 shows the results obtained from testing various types of media available.

Based on the results obtained ABCUT media was most suitable for deflashing process. Since the amplitude obtained using this media is high we made use of the same media for the cryogenic deflashing process.

The results obtained from testing of various rubber samples with ABCUT media are as shown in Table 2. Fig. 4 shows the original and deflashed samples. Tests are also carried out on other types of samples. The results are equally good in all the types of samples tested.

\section{Conclusions}

This section describes the overall conclusions drawn from the work carried out and the results obtained. A cryogenic deflashing technique through which the flashes can be removed easily and effectively was identified. Based on the test results obtained from 
testing of five different types of media, ABCUT Steel media gave best results. The testing of the ABCUT Steel media on rubber samples like O-rings, grommet tail door, bottom bush, etc., showed good results.

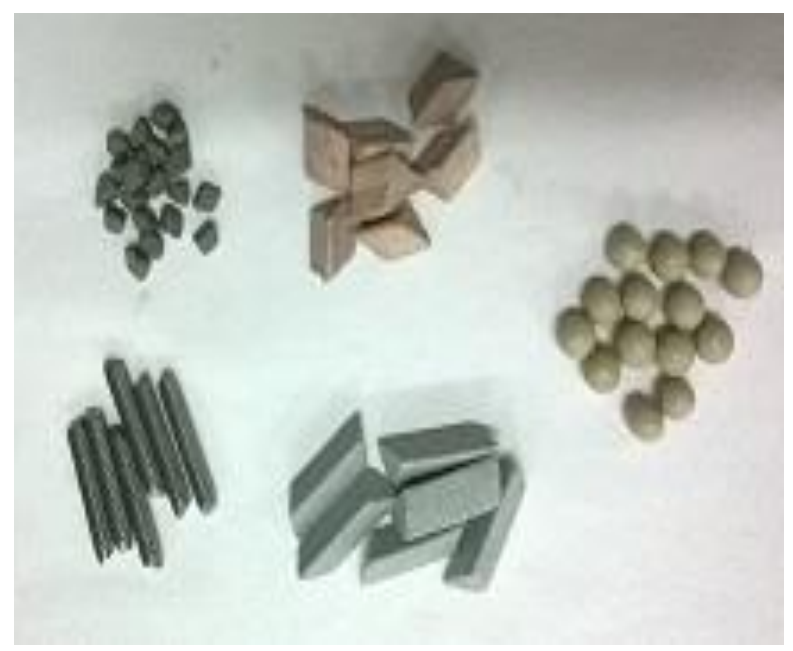

Fig. 3. Different types of media

Table 1. Results from different types of media

\begin{tabular}{|c|c|c|c|c|}
\hline Media & Type of Sample & $\begin{array}{c}\text { No. of } \\
\text { samples }\end{array}$ & $\begin{array}{c}\text { No. of } \\
\text { accepted } \\
\text { samples }\end{array}$ & $\begin{array}{c}\text { Amplitude } \\
\text { (mm) }\end{array}$ \\
\hline $\begin{array}{c}\text { Alumina } \\
\text { Deburring } \\
4 \text { X } 4\end{array}$ & O-Ring(55mm) & 10 & 5 & $1.5-2$ \\
\hline $\begin{array}{c}\text { Ceramic } \\
\text { Ball }\end{array}$ & O-Ring $(55 \mathrm{~mm})$ & 10 & 1 & $\begin{array}{c}\text { Less than } \\
1.5\end{array}$ \\
\hline $\begin{array}{c}\text { T8X20 } \\
\text { Grey cut }\end{array}$ & O-Ring $(55 \mathrm{~mm})$ & 10 & 4 & $2-2.5$ \\
\hline Tri star & O-Ring $(55 \mathrm{~mm})$ & 10 & 8 & $3-3.5$ \\
\hline ABCUT & O-Ring $(55 \mathrm{~mm})$ & 10 & 10 & $3.5-4$ \\
\hline
\end{tabular}

Table 2. Results from different samples tested

\begin{tabular}{|c|c|c|c|}
\hline Type of sample & No. of Sample & $\begin{array}{l}\text { Total time } \\
\text { (minutes) }\end{array}$ & $\begin{array}{l}\text { No. of okay } \\
\text { samples }\end{array}$ \\
\hline O-RINGS & 150 & 90 & 140 \\
\hline Grommet Tail Door & 50 & 90 & 42 \\
\hline Bottom bush & 50 & 90 & 44 \\
\hline
\end{tabular}




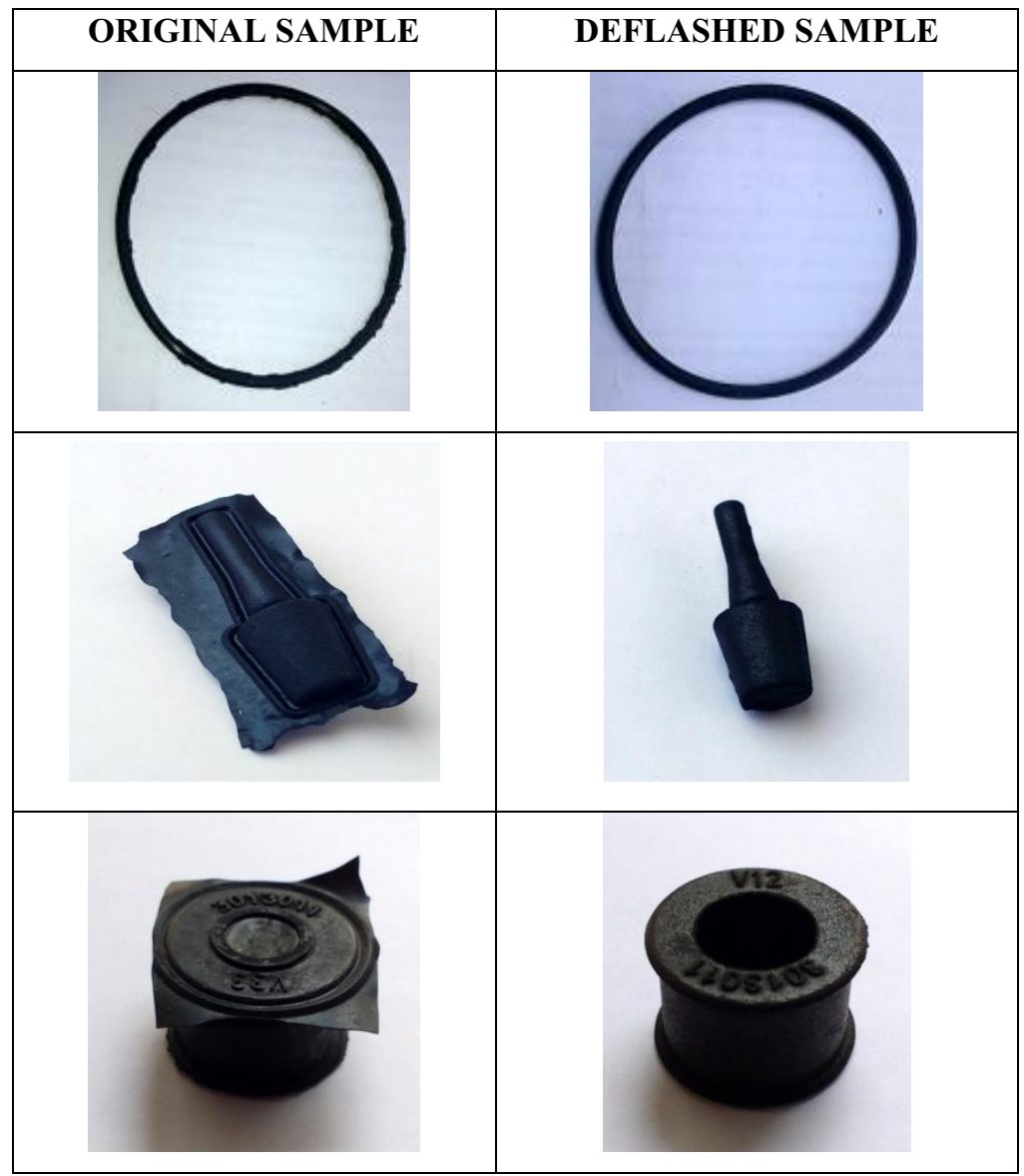

Fig. 4. Results from different samples tested

\section{References}

1. D. Spooner, J Mech. Engg., 10, 209 (1984)

2. R. M. Leliaert, S Bend, U.S. Patent, 2,996,846, (1959)

3. R. A. Rhodes, www.cryogenicsociety.org, (2010)

4. R. Wieland, Cold Facts, (1997)

5. H. Li, S. Zhu, M. Dubois, Technical bulletin, Solvay (2015)

6. CRYOGENIC DEFLASHING: A REVIEW, Maxi- Blast, Inc.

7. R. A. Potterfield, T. Morrow, U.S. Patent, 7,883,396 (2011)

8. P. Warrier, http://rubbermachineryworld.com, (2015) 